\title{
Protein Phosphatase 1D
}

National Cancer Institute

\section{Source}

National Cancer Institute. Protein Phosphatase 1D. NCI Thesaurus. Code C88190.

Protein phosphatase 1D (605 aa, $67 \mathrm{kDa}$ ) is encoded by the human PPM1D gene. This protein plays a role in the mediation of cell cycle arrest. 